\title{
Analysis of Food Inflation in Java and Sumatra Islands
}

\author{
Nairobi*, Laura Caroline \\ Faculty of Economics and Business, University of Lampung, Lampung, Indonesia \\ * nairobi@feb.unila.ac.id
}

\begin{tabular}{|c|c|}
\hline Article Info & Abstract \\
\hline Received : 2021-04-19 & \multirow{4}{*}{$\begin{array}{l}\text { The purpose of this study is to analyze the factors of food inflation } \\
\text { in Java and Sumatra. This study uses Panel Data regression analysis } \\
\text { to identify inflation and uses a panel data model from } 2013-2019 \\
\text { with a sample of } 16 \text { provinces in Sumatra and Java, to determine the } \\
\text { effect of each variable on the Consumer Price Index. The results of } \\
\text { this study indicate that from the panel data regression analysis that } \\
\text { the independent variables of the World Food Price Index, the } \\
\text { Average Price of Onions, Rice, Chili and Chicken in the Provincial } \\
\text { Capital have an effect on the Consumer Price Index, while Per } \\
\text { Capita PDRB does not have a significant effect on the Consumer } \\
\text { Price Index in the Province. Java and Sumatra. }\end{array}$} \\
\hline Accepted : 2021-07-13 & \\
\hline Published : 2021-07-30 & \\
\hline $\begin{array}{l}\text { Key words: consumer price } \\
\text { index, world food price index, per } \\
\text { capita GRDP, onion price, rice } \\
\text { price, chilli price and chicken } \\
\text { price. }\end{array}$ & \\
\hline
\end{tabular}

\section{INTRODUCTION}

Inflation is one of the economic phenomena in a country. The movement of inflation is a picture of the general price increase that is happening. Inflation is a process of increasing general prices of goods continuously, it does not mean that the prices of various goods increase by the same percentage. The most important thing is that there is an increase in the general price of goods continuously during a certain period (Nopirin, 2000). Inflation in Indonesia had reached its highest point, namely in 1966 and 1998. Inflation in 1966 was the highest inflation in the 1960s, while in 1998 it was the highest inflation since the New Order era.

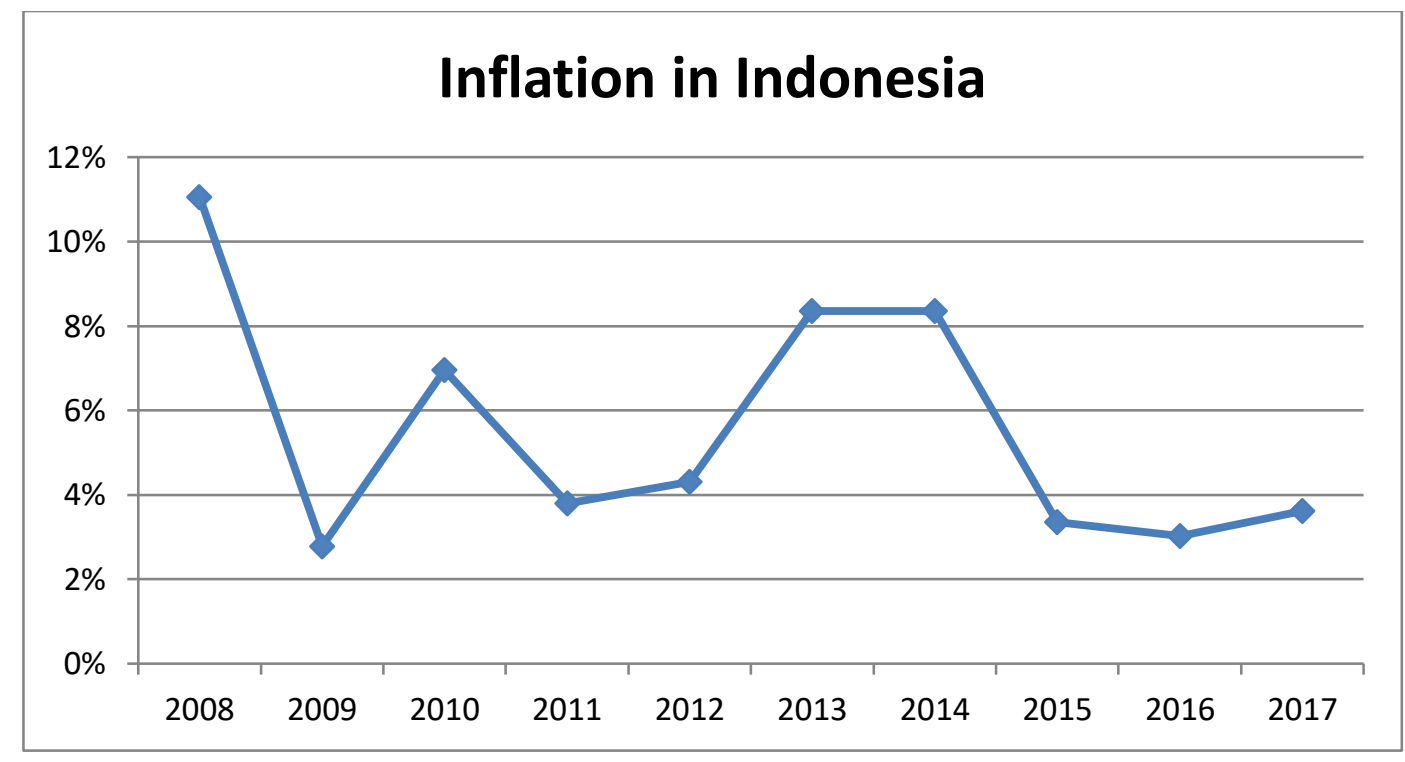

Source: Bank Indonesia, 2018

Inflation in Indonesia itself has fluctuated from year to year. In figure 1, from 2008 to 2017 inflation fluctuated. The highest inflation occurred in 2008 with the global economic crisis that occurred in the same year, starting with the US economic crisis and then spreading to other 
countries around the world, including Indonesia. Then in 2009 inflation control fell to $2.78 \%$. In 2015, inflation experienced a decline to $3.35 \%$, which previously reached $8.36 \%$ in 2014 . According to a consumer survey conducted by Bank Indonesia that year, this was influenced by weak household consumption and consumer pessimism over job availability in 2015 (Bank Indonesia, 2015).

The Consumer Price Index (CPI) is an important economic indicator that can provide information on the development of prices for goods and services (commodities) paid by consumers or the public. The CPI in Indonesia is grouped into several expenditure groups, namely the foodstuffs group, the processed food group, beverages, cigarettes and tobacco, the housing, water, electricity, gas and fuel group, the clothing group, the health group, the education, recreation and sports group, the group transport, communication and financial services. The foodstuff group is one of the major CPI contributors in this expenditure group. Food prices have become more flexible and volatile so that food price inflation worries producers and consumers (Roache, 2010).

Increases in food prices always occur close to religious holidays such as Eid Al-Fitr, Christmas and even New Years. This is influenced by the lack of supply of foodstuffs when demand increases, so that prices jump up. Kornher \& Kalkuhl (2013) found that supply-side stocks and production have a significant effect on domestic food prices. This annual phenomenon often occurs and causes inflation in Indonesia to increase, one of which is contributed by the foodstuff expenditure group. It is important to control food inflation in Indonesia mainly due to two reasons, namely the persistent nature of food inflation and its impact on the relatively high decline in purchasing power compared to other commodities.

According to data reported by BPS, inflation in June 2018 drove food inflation by 0.88 percent, the food sub-group that experienced the highest inflation was the vegetables sub-group at 2.86 percent and the lowest was nuts at 0.36 percent. The increase in food prices always occurs before holidays and always recurs every year.

Inflation occurring in Indonesia according to the expenditure groups presented in the graph above shows that inflation for foodstuffs has the highest percentage each year compared to the processed food, cigarettes, tobacco, housing, water, electricity, gas, fuel and clothing group (Central Agency Statistics). In Indonesia, the prices of food commodities that often experience price fluctuations include rice, corn, soybeans, wheat flour, sugar, cooking oil, shallots, chilies, eggs, meat and milk.

Based on BPS data, foodstuff is the component that most influences the 2018 inflation rate, with a share of $0.68 \%$. In addition, the inflation rate for foodstuffs in 2018 , which was $3.41 \%$, was the inflation group that increased the most from last year. The inflation rate for the foodstuff category in 2017 was only $1.26 \%$. In the foodstuff group that boosted inflation in 2018 by the rice sub-group with a share of $0.13 \%$, followed by broiler chicken with a share of $0.12 \%$, and fresh fish with a share of $0.1 \%$. Bank Indonesia (BI) through the Price Monitoring Survey (SPH) in February 2018 recorded BI's SPH in 82 cities with a sample of two markets in each city, finding sources of national inflationary pressure, from volatile food prices groups in Java and Sumatra. Volatile food inflation in Java and Sumatra was higher than the same period three years ago. These volatile food commodities include rice, red chilies and garlic.

In 2014 the highest CPI on the island of Sumatra was owned by Bengkulu and followed by West Sumatra and Jambi, for Java Island the highest CPI was in Banten province followed by Central Java and East Java provinces. In 2015, the highest CPI was in West Sumatra Province followed by North Sumatra and Lampung Provinces for Sumatra and Java provinces in Banten, DKI Jakarta and East Java. According to the 2015 BI Monetary Publication, overall inflation was contributed by price component deflation and the relatively low core inflation during that year. Inflation in the foodstuff category was relatively under control amid the occurrence of El Nino symptoms that year. In 2016 the CPI was in the provinces of Bengkulu, 
North Sumatra and West Sumatra on the island of Sumatra. On the island of Java, the highest CPI is in the Provinces of Banten, DKI Jakarta and East Java.

The increase in food prices in parts of the world is a unique phenomenon for some people who see its connection with macroeconomic developments and its relationship with inflation. An increase in food prices based on macroeconomic logic can lead to an increase in inflation. In relation to developing countries, this occurs because the average food consumption occupies the largest portion of the level of public consumption. Kornher \& Kalkuhl (2013) states that commodity prices in Indonesia such as sugar, cooking oil, soybeans and corn are related to world food prices. In a period of about one year, a one percent increase in the average price of world food commodities will result in an increase of one percent in the domestic food price in Indonesia. Other commodities will respond to the same thing with varying response times.

In Indonesia, there are several foodstuffs that always experience price fluctuations, especially when approaching religious holidays such as Eid al-Fitr, Christmas and other major holidays. Food prices are one of the factors contributing to inflation in Indonesia. The November 2016 Bank Indonesia report stated that inflation in September 2016 was triggered by an increase in food prices, especially the prices of chilies and shallots (Bank Indonesia, 2016). Foodstuffs that are constantly changing in price originate from the staple foodstuffs which are the daily consumption of Indonesians, especially Java and Sumatra. These foods include rice, corn, onions, garlic, red chilies, chicken meat and other foodstuffs. The price of foodstuffs fluctuates in line with foodstuffs which is a primary need and plays a very strategic role so that if food price volatility occurs, it will affect inflation and economic growth. Therefore, the impact of the volatility of staple food prices on macroeconomic indicators is a major research question.

Ismaya \& Anugrah (2018) show that inflation in Indonesia is significantly influenced by backward and forward looking expectations, food production, GDP, infrastructure and other variables included in the model. Pratikto \& Ikhsan (2016) show that monetary policy can effectively prevent the spillover effect of food inflation to non-food inflation. In addition, exchange rate stability can play a role in reducing volatility in food inflation, especially in the long term.

\section{LITERATURE REVIEW}

\section{Theoretical base}

\section{Inflation}

The indicator that is often used to measure the rate of inflation is the Consumer Price Index (CPI). Changes in the CPI from time to time indicate price movements of packages of goods and services consumed by the public. The determination of goods and services in the CPI basket is carried out on the basis of the Cost of Living Survey ( $\mathrm{SBH}$ ) conducted by the Central Statistics Agency (BPS). The increase in price is measured using a price index.

Inflation as measured by the CPI in Indonesia is grouped into 7 expenditure groups, namely (1) foodstuffs; (2) Prepared food, beverages, cigarettes and tobacco; (3) Housing, water, electricity, gas and fuel; (4) Clothing; (5) Health; (6) Education, recreation and sports; (7) Transportation, communication and financial services. Foodstuffs are one of the expenditure groups that have a big role in the CPI as a whole. The percentage of foodstuffs is contributed from staple goods which are important commodities in Indonesia.

\section{Quantity Theory}

In principle, this quantity theory states that the emergence of inflation is only caused by an increase in the amount of money in circulation and not due to other factors (Mankiw, 2019). Based on this theory, there are 2 factors that cause inflation, namely the amount of money in 
circulation. The greater the amount of money circulating in society, the higher inflation will also be. Therefore, the government should take into account or predict the inflation that would occur if it wanted to make additional printing of new money, because printing new money that was too large would cause economic turmoil.

Furthermore, the public estimates/assumptions that prices will rise. If people think that prices will increase, there is no tendency to save cash anymore, people will save their money in the form of goods so that demand will increase. This pushes the price up continuously.

\section{Keynesian Theory}

According to this theory, inflation occurs because people want to live beyond their economic limits. Thus the public demand for goods exceeds the available quantity. This happens because people know what they want and make that desire in the form of an effective demand for goods. When the amount of demand for goods increases, at a certain price level, exceeds the maximum number of goods that can be produced by society, inflationary will arise. This situation causes prices to rise and means that the purchase plan cannot be fulfilled. In the next period the community will try to obtain even more funds (either from printing new money or from credit at banks and requesting a salary increase)(Mankiw, 2019).

\section{Structuralist Theory}

Structuralist theory is also called the theory of long-term inflation because it highlights the causes of inflation that stem from the economic structure, particularly the supply of foodstuffs and export goods. The increase in the production of goods is not proportional to the growth in demand, as a result there is an increase in the price of foodstuffs and a scarcity of foreign exchange. Next is an even increase in the price of goods resulting in inflation. Inflation of this kind cannot be overcome only by reducing the amount of money in circulation, but must be overcome by increasing productivity and the development of the food and export goods sector (Mankiw, 2019).

\section{Economic growth}

\section{Classical Theory}

According to the views of classical economists, there are four factors that influence economic growth, namely: population, stock of capital goods, land area and natural wealth and level of economy used. Economic growth depends on many factors and classical economists especially focused their attention on the effect of population growth on economic growth. In this theory, it is assumed that the area of land and natural resources is constant and the level of technology does not change. Initially, the population is relatively small and natural wealth is relatively excessive, the return on capital from investment will be higher and investors or entrepreneurs will experience more profits, which will lead to new investment and economic growth will be realized. However, this will not continue. Furthermore, if the population is too large, the increase will decrease the level of economic activity because the productivity of each population has become negative, so that the prosperity of the community decreases. This situation will be referred to as an underdeveloped economic condition and workers' income only reaches the level of living (Krugman \& Wells, 2018).

\section{Rostow's theory}

The theory of growth stages was developed by WW Rostow and disseminated through his book published in 1960 with the title "The Stages 0 Economic Growth: a non-comunist manifesto". According to Rostow, the process of economic development can be divided into 5 stages, namely traditional society, take-off society, take-off stage, the stage of movement towards maturity, and the stage of high mass consumption (Rostow, 1959). 


\section{World Food Price Index}

The commodities covered in the world food production index calculation are all plants and livestock products originating from their respective countries. Practically all products are covered, with the main exception for animal feed. The food category includes commodities that are considered edible and which contain nutrients. The increase in food prices is related to macroeconomic developments and to inflation. An increase in food prices, based on macroeconomic logic, can lead to an increase in inflation. In relation to developing countries, this occurs because the average food consumption occupies the largest portion of the level of public consumption (FOA, 2013).

\section{Prices of Onions, Rice, Chili and Chicken}

Commodities Onions, Rice, Chili and Chicken are very strategic commodities in the country to become a benchmark for food availability for Indonesia. Prices of onions, rice, chili and chicken fluctuate and efforts to increase production and price stability are important things that must be done. Sufficient availability of these foodstuffs at affordable prices has become the main objective of agricultural development policies. Food shortages can cause economic, social and political insecurity that can destabilize national stability (FOA, 2013).

\section{Hypothesis}

1. It is suspected that the World Food Price Index has a positive and significant effect on Food Inflation in 16 (sixteen) provinces in Java and Sumatra for the period 2013-2019.

2. It is suspected that PDRB per capita has a positive and significant effect on food inflation in 16 (sixteen) provinces in Java and Sumatra for the period 2013-2019.

3. It is suspected that Rice Prices have a positive and significant effect on Food Inflation in 16 (sixteen) provinces in Java and Sumatra for the period 2013-2019.

4. Price of onions positive and significant effect on Food Inflation in 16 (sixteen) provinces in Java and Sumatra for the period 2013-2019.

5. Prices of Chili positive and significant effect on Food Inflation in 16 (sixteen) provinces in Java and Sumatra for the period 2013-2019.

6. Chicken Prices have a positive and significant effect on Food Inflation in 16 (sixteen) provinces in Java and Sumatra for the period 2013-2019.

Based on the theoretical foundation that has been described, a concept will be drawn that will be used as an approach as a research reference, then the authors try to explain and apply in the main research problems described in the following frame of mind:

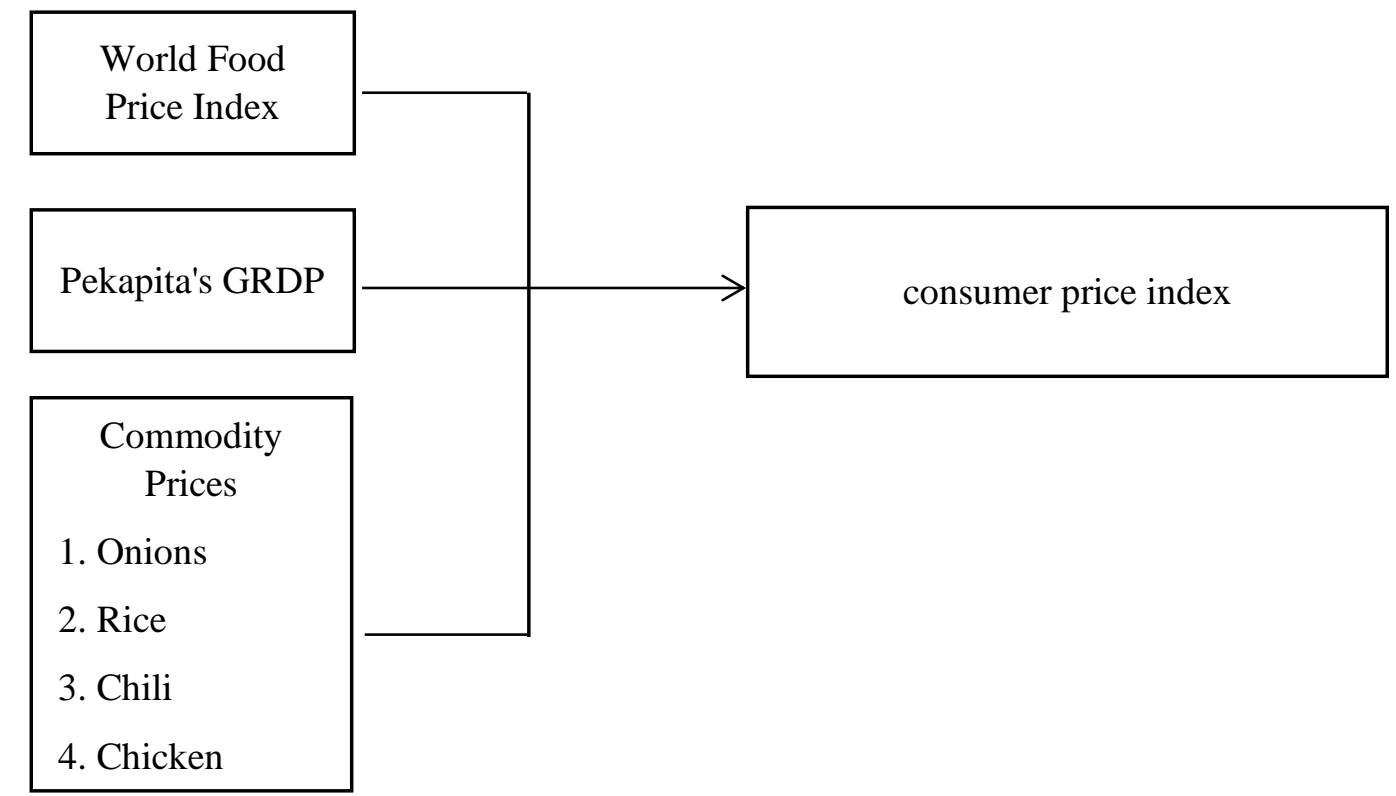

Source: Developed by the authors, 2021 


\section{METHODS}

Data

Data was obtained from data collection agencies, namely the Central Statistics Agency (BPS) and the Publication of Agricultural Commodity Price Statistics by the Ministry of Agriculture and the Agriculture Organization of the United Nation and other related sources. The type of data collected is panel data, which is a combination of time series data and cross section data. With an annual time-series, namely 2013-2019 and a cross section of 16 (sixteen) provinces on the islands of Java and Sumatra, namely DKI Jakarta, West Java, Central Java, Yogyakarta, East Java, Banten Aceh, North Sumatra, West Sumatra, Riau, Jambi, South Sumatra, Bengkulu, Lampung, Bangka Belitung Islands, and Riau Islands. Consumer Price Index, World Food Price Index (WPI), PDRB Per capita, Onion Prices, and Rice Prices is the data that will be examined in this study.

\section{Operational Definition of Variables and Variable Measurements}

The existence of independent variables used, will affect the dependent variable in the study. Y is the symbol of the dependent variable. The Consumer Price Index for foodstuffs in 16 (sixteen) provinces in Java and Sumatra in 2013-2019 in percent (\%) is the dependent variable in this study. The variable that causes changes in the dependent variable is the independent variable. The World Food Price Index (WPI), GRDP Per capita, Shallot Prices, Rice Prices, Chili Prices and Chicken Cut Prices are independent variables in this study.

\section{World Food Price Index}

The world food production index calculates the commodities included in the calculation are all crops and livestock products originating from their respective countries Almost all products are covered, with the main exception for animal feed. The food category includes commodities that are considered edible and contain nutrients. The data is obtained from the Agriculture Organization of the United Nation website from 2013-2019.

\section{PDRB Per Capita}

Gross Regional Domestic Product (PDRB) per capita at constant prices according to users with 2010 as the base year obtained from the Central Statistics Agency (BPS) for 16 (sixteen) provinces on the islands of Java and Sumatra in the 2013-2019 period in million rupiah units.

\section{Price of onions}

The average price of shallots in the provincial capital is the price of shallots used in this study. This data was obtained from the Ministry of Agriculture through the publication of agricultural commodity price statistics in 2019 for each of the 16 (sixteen) provinces in Java and Sumatra in the 2013-2019 period in Rupiah/Kg units.

\section{Price of Rice}

The price of rice used in this study uses the average commodity price of retail rice in provincial capitals. This data was obtained from the Ministry of Agriculture through the publication of agricultural commodity price statistics in 2019 for each of the 16 (sixteen) provinces in Java and Sumatra in the 2013-2019 period in Rupiah/Kg units.

\section{Prices of Chili}

The price of chili used in this study uses the average commodity price of curly red chilies in the provincial capital. This data was obtained from the Ministry of Agriculture through the publication of agricultural commodity price statistics in 2019 for each of the 16 (sixteen) provinces on the islands of Java and Sumatra in the 2013-2019 period in Rupiah/Kg units. 


\section{Price of Chicken}

The price of chickens used in this study uses the average commodity price of broiler chickens in the provincial capital. This data was obtained from the Ministry of Agriculture through the publication of agricultural commodity price statistics in 2019 for each of the 16 (sixteen) provinces in Java and Sumatra in the 2013-2019 period in Rupiah/Kg units.

\section{Data Analysis}

Baltagi (2005) stated that there are several advantages to using panel data as an analytical tool, namely, first, individual heterogeneity is controlled. Individuals, companies, places or countries are heterogeneous which are expressed in the data panel. The dependent variable can be affected by the state invariant and time because the panel data contains an element of time which causes other variables to also experience the same thing. There is a possibility that there is a heterogeneous treatment of each individual. Panel data is also suitable for studying the duration of economic magnitude variables such as unemployment, poverty and inflation and can also explain the speed of response to changes in economic policy. In the analysis with the panel data model, there are three kinds of estimation approach methods that are commonly used:

\section{Common Effect Model (CEM)}

The simplest technique for estimating panel data is to only combine the time series data and the cross section. By simply combining these data without looking at the differences between time and individuals, we can use the Common Effect method to estimate the panel data model. This method is known as Common Effect estimation. In this approach, it does not pay attention to individual dimensions or time (Baltagi, 2015).

\section{Fixed Effect Model (FEM)}

A model that assumes different interceptions in the equation is known as the Fixed Effect regression model. Fixed Effect model technique is a technique of estimating panel data using dummy variables to capture differences in interceptions. The definition of Fixed Effect is based on the difference in intercept, but the intercept is the same between times. In addition, this model assumes that the regression coefficient is fixed between firms and over time. This estimation model is often referred to as the Least Squares Dummy Variables (LSDV) technique (Baltagi, 2015).

\section{Random Effect Model (REM)}

The random effect approach is an approach taken to improve the inefficiency of the least square process by taking into account the errors of the cross-section and time series. The random effect model is a variation of the generalized least square estimation. This approach assumes that the unobservable individual effect does not correlate with the regressor or in other words is random (Baltagi, 2015).

\section{Chow test}

The specification test aims to determine the panel data analysis model to be used. The Chow test is used to choose between the fixed effect model or the common effect/Pooled Least Square (PLS) model which should be used (Baltagi, 2015). The hypotheses used are:

$\mathrm{H}_{0}$ : using the Common Effect model approach.

$\mathrm{H}_{\mathrm{a}}$ : using the Fixed Effect model approach

When the selected model is a fixed effect, it is necessary to do another test, namely the Hausman test to find out whether it is better to use a fixed effect model (FEM) or a random effect model (REM) (Baltagi, 2015).

\section{Hausman Test}

This test aims to determine which model should be used, namely the fixed effect model (FEM) or the random effect model (REM). In FEM, each object has a different intercept, but the 
intercept of each object does not change over time. This is known as time-invariant. Whereas in REM, the (shared) intercept represents the average value of all the intercepts (cross section) and the components represent the (random) deviation of the individual intercept to the mean value (Baltagi, 2015).

The hypothesis in the Hausmann test is as follows:

$\mathrm{H}_{0}$ : using the Random Effect Model approach

$\mathrm{H}_{\mathrm{a}}$ : using the Fixed Effect Model approach

If hypothesis $\mathrm{H}_{0}$ is rejected, then the conclusion should use FEM. Because REM is likely correlated with one or more independent variables. Conversely, if $\mathrm{Ha}$ is rejected, the model that should be used is REM.

\section{Lagrange Multiplier (LM) test}

If from the previous two tests the results obtained in one test or even both tests received $\mathrm{H}_{0}$, then a test called the Lagrange Multiplier (LM) test is carried out which is also called the BreuschPagan Random Effect. However, if this is not the case, then this test is not necessary. This test is carried out to select the analysis technique that will be used best among the common effect model and the random effect model (Baltagi, 2015). The hypothesis used in this test is as follows:

\section{$\mathrm{H}_{0}$ : Common Effect Model}

\section{$\mathrm{H}_{\mathrm{a}}$ : Random Effect Model}

The Lagrange Multiplier test results will be seen the chi-square statistical value of the processed eviews data. If the value of the Lagrange Multiplier test is greater than the critical value of the chi-squares statistic, then $\mathrm{H}_{0}$ is rejected. In other words, the random effect model will be used because it is considered better. If the value of the Lagrange Multiplier Test results is below the critical value of the chi-square statistic, then $\mathrm{H}_{0}$ is accepted. If $\mathrm{H}_{0}$ is accepted, it can be concluded that it is better to use the random effect model (Baltagi, 2015).

\section{Statistical t-test}

According to Gujarati \& Porter (2009), the individual parameter significance test (t-statistical test) looks at the relationship or influence between individual independent variables on the dependent variable. The test criteria are as follows:

If $\mathrm{H}_{0}$ is rejected, it means that the tested independent variable has a significant effect on the dependent variable. If $\mathrm{HO}$ is accepted, it means that the tested independent variable has no real effect on the dependent variable. In this study, the t-test is as follows:

1) World Food Price Index

H0: $\beta 1 \leq 0$, it means that the World Food Price Index variable has no effect on the Consumer Price Index.

Ha: $\beta 1>0$, meaning that the World Food Price Index variable has a significant effect on the Consumer Price Index.

2) PDRB Per Capita

H0: $\beta 2 \leq 0$, meaning that the GDP per capita variable does not have a significant effect on the Consumer Price Index

Ha: $\beta 2>0$, meaning that the GDP per capita variable has a significant effect on the Consumer Price Index

3) Price of onions

H0: $\beta 3 \leq 0$, meaning that the Onion Price variable does not have a significant effect on the Consumer Price Index 
Ha: $\beta 3>0$, meaning that the Onion Price variable has a significant effect on the Consumer Price Index

4) Price of Rice

H0: $\beta 4 \leq 0$, meaning that the Rice Price variable does not have a significant effect on the Consumer Price Index

Ha: $\beta 4>0$, meaning that the Rice Price variable has a significant effect on the Consumer Price Index

5) Prices of Chili

H0: $\beta 5 \leq 0$, it means that the Chili Price variable does not have a significant effect on the Consumer Price Index

Ha: $\beta 5>0$, meaning that the Chili Price variable has a significant effect on the Consumer Price Index

6) Price of Chicken

H0: $\beta 6 \leq 0$, meaning that the Chicken Price variable does not have a significant effect on the Consumer Price Index

Ha: $\beta 6>0$, meaning that the Chicken Price variable has a significant effect on the Consumer Price Index

\section{Significance Test (Test F)}

According to Gujarati \& Porter (2009), the significance test (F test) is carried out to determine whether together all independent variables have a significant or insignificant effect on the dependent variable. The hypothesis that is formulated is:

$\mathrm{H}_{0}:=0$, all independent variables have no significant effect on the dependent variable.

$\mathrm{H}_{\mathrm{a}}: \neq 0$, all independent variables have a significant effect on the dependent variable.

The test criteria are $\mathrm{H}_{0}$ rejected and $\mathrm{H}_{\mathrm{a}}$ accepted, if F-count> F-table, $\mathrm{H}_{0}$ accepted and $\mathrm{H}_{\mathrm{a}}$ rejected, if F-count $<$ F-table.

\section{RESULTS}

\section{Results}

Table 1. Descriptive Statistics Test Results

\begin{tabular}{|c|c|c|c|c|c|}
\hline & $\mathrm{N}$ & $\begin{array}{l}\text { Descriptive } \\
\text { Minimum } \\
\text { in percent }\end{array}$ & $\begin{array}{l}\text { ics } \\
\text { Maximum } \\
\text { in percent }\end{array}$ & $\begin{array}{c}\text { Mean } \\
\text { in percent }\end{array}$ & $\begin{array}{c}\text { Std. } \\
\text { Deviation }\end{array}$ \\
\hline consumer price index & $\begin{array}{c}11 \\
2\end{array}$ & 112,000 & 184,000 & 141,071 & 17,236 \\
\hline World Food Price Index & $\begin{array}{c}11 \\
2\end{array}$ & $-34,300$ & 15,900 & 0.869 & 13,417 \\
\hline GRDP per capita & $\begin{array}{c}11 \\
2\end{array}$ & 9,800 & 12,100 & 10,498 & 0.531 \\
\hline Price of onions & $\begin{array}{c}11 \\
2\end{array}$ & 9,200 & 10,700 & 10,179 & 0.290 \\
\hline Price of Rice & $\begin{array}{c}11 \\
2\end{array}$ & 8,900 & 10,600 & 9,264 & 0.299 \\
\hline Prices of Chili & $\begin{array}{c}11 \\
2\end{array}$ & 9,900 & 10,800 & 10,346 & 0.202 \\
\hline Price of Chicken & $\begin{array}{c}11 \\
2 \\
\end{array}$ & 9,800 & 10,500 & 10,294 & 0.131 \\
\hline
\end{tabular}

Source: computed data 
Table 2. Panel Data Regression Results for Economic Growth Bound Variables

\begin{tabular}{lccc}
\hline Variable & CEM & FEM & BRAKE \\
\hline Constant & 67,499 & 751,101 & 67,499 \\
& $(0.605)$ & $(0,000) * *$ & $(0.554)$ \\
World Food Price Index & 0.696 & 0.561 & 0.696 \\
(WPI) & $(0,000) *$ & $(0,000) *$ & $(0,000) *$ \\
Gross Regional Domestic Product & 2,309 & 14,502 & 2,309 \\
(GRDP) & $(0.372)$ & $(0.429)$ & $(0.307)$ \\
Price of onions & 11,647 & 32,236 & 11,647 \\
(Onion) & $(0.108)$ & $(0,000) *$ & $(0.066) * *$ \\
& 2,813 & 13,720 & 2,813 \\
Price of Rice & $(0.633)$ & $(0.064) * *$ & $(0.585)$ \\
(Rice) & $-17,996$ & 40,021 & $-17,996$ \\
Prices of Chili & $(0.052) * *$ & $(0.001) *$ & $(0.026) *$ \\
(Chili) & 8,773 & 48,519 & 8,772 \\
Price of Chicken Cut & $(0.441)$ & $(0.005) *$ & $(0.378)$ \\
(Chicken) & & 3,173 & \\
Chow test & & $(0,000) *$ & \\
& & 40,237 & \\
Hausman test & & $(0,000) *$ & \\
& & &
\end{tabular}

Source: Eviews 9.0 Output

Note: *) significant at $\alpha=5 \%$ and $* *)$ significant at $\alpha=10 \%$

Based on the chow test results, it shows that the Fixed Effect Model is better than the Random Effect Model, while the Hausman test results show that the Fixed Effect Model is better than the Random Effect Model so that the Fixed Effect Model is best used in this study. $\mathrm{CPI}=751,101+0,561 \mathrm{WPI} *+14,502 \mathrm{PDRB}+32,236$ Onions $*+13,720$ Rice $* *+40,021$

$\mathrm{R} 2=0.619$

Chilli $*+48,519$ Chicken $*$

DWstatistic $=1,916$

Note: ${ }^{*}$ ) significant at $\alpha=5 \%$ and $\left.* *\right)$ significant at $\alpha=10 \%$

The calculation results show that the world food price index, onion prices, rice prices, chili prices, and chicken prices have a significant and positive effect on the Consumer Price Index. Meanwhile, gross domestic product has no significant effect on the Consumer Price Index.

\section{DISCUSSION}

\section{The Effect of the World Food Price Index on the Consumer Price Index}

The World Food Price Index has a significant positive effect on the Consumer Price Index, this shows that if the ratio of the world food price index increases, it will increase the Consumer Price Index, ceteris paribus. Ismaya \& Anugrah (2018) state that Food Prices have a positive and significant influence in influencing inflation. World Food Prices are an external factor that affects food price fluctuations in Indonesia, particularly in Java and Sumatra. World food prices also illustrate the fluctuations in food prices that occur in society. 


\section{PDRB Per Capita to Consumer Price Index}

Gross Regional Domestic Product (PDRB) per capita has no significant effect on the Consumer Price Index. This is not in accordance with the research hypothesis that there is no effect of GDP per capita on the consumer price index. This is because revenue does not directly affect the prevailing price level.

\section{Onion Prices to the Consumer Price Index}

The price of onions has a significant and positive effect on the Consumer Price Index, meaning that if there is an increase in the price of onions, it will increase the Consumer Price Index, ceteris paribus. Rizaldy (2017) who found a positive and significant effect of Onion Prices on inflation in Malang City. This is also supported by the publication of the Ministry of Trade in the 2015-2019 Food Outlook summary report where the productivity of shallots increases by 2 percent in one year and production is concentrated in only 4 provinces which are Indonesia's shallot production centers, namely Central Java, East Java, West Java. and West Nusa Tenggara. The publication of the Ministry of Trade states that the price of shallots in Indonesia continues to increase and is increasingly fluctuating, and peak production occurred in the third quarter for five consecutive years and also the price of Indonesian shallots was much higher than the international price of shallots. This happens because the shallot commodity is a commodity that is strongly influenced by weather factors (Kemendagri, 2019).

\section{Rice Prices against the Consumer Price Index}

The price of rice has a significant and positive effect on the Consumer Price Index, meaning that if there is an increase in the price of rice, it will increase the Consumer Price Index, ceteris paribus. Saraswati \& Kaluge (2017) who found a positive and significant effect which found that rice prices had an effect on inflation. It is also labeled because rice is still the staple food of most people in Indonesia, especially Java and Sumatra. So that the increase in rice prices will cause an increase in inflation. Rangasamy (2011) and Adam et al. (2012) give results that food prices have a strong influence on the inflation rate. Ismaya \& Anugrah (2018) also found that inflation caused by the rice commodity was influenced by the supply side, namely production, land.

\section{Chili Prices against the Consumer Price Index}

The price of chili has a significant and positive effect on the Consumer Price Index, meaning that if there is an increase in the price of chili, it will increase the Consumer Price Index, ceteris paribus. Allegedly because chili is a staple food commodity. And the increase in the price of chili causes an increase in general prices so that it significantly affects inflation. Because the definition of inflation is a continuous increase in prices, so that a momentary increase in prices is not said to be inflation. The government, through the Ministry of Trade, controls the food price set by the Minister of Trade Regulation concerning Reference Prices for Purchases at Farmers and Reference Prices for Sales at Consumers. Setting the reference price is the government's effort to control prices at the consumer level (Kemendagri, 2019).

\section{Chicken Prices against the Consumer Price Index}

Chicken prices have a significant and positive effect on the Consumer Price Index, meaning that if the price of chicken increases, it will increase the Consumer Price Index, ceteris paribus. This is motivated by the price of chicken which is more affordable than beef, which can be used as a source of animal protein. Domestic consumption of chicken meat reaches 42.80 percent, the use of chicken meat for industrial raw materials reaches 9.46 percent and restaurant or catering businesses reach 2.59 of the total consumption of chicken meat in Indonesia for the period 2017 (Badan Pusat Statistik, 2017). Based on the 2017 National Socio-Economic Survey (Susenas) data, the largest consumption of chicken meat is owned by the provinces of West Java, East Java and Central Java on a national scale. This is supported by high household consumption and 
the large number of culinary businesses made from chicken meat. The province of Sumatra, which has the highest level of chicken meat consumption, is owned by the provinces of North Sumatra, Riau and South Sumatra.

\section{CONCLUSIONS AND SUGGESTIONS}

\section{Conclusion}

The results of this study indicate that The World Food Price Index, the price of onions, the price of rice, the price of chili, and the price of chicken have a positive effect on the Consumer Price Index, while the GDP per capita does not have a significant effect. Food prices illustrate the fluctuations in food prices that occur in society. Policies to manage food prices so that price volatility can be minimized must be continued. However, the policies implemented must side with producers and consumers, because both are actors of consumption as well as parties that produce commodities.

\section{Suggestion}

The central government must cooperate with local governments where food commodities are produced so that distribution by implementing supply chain management will make both types of commodities more efficient. Logistics and post-harvest improvements allow both commodities to be made available to consumers on time and can even be distributed outside of the harvest season.

\section{REFERENCES}

Adam, C., Kwimbere, D., Mbowe, W., \& O'Connell, S. (2012). Food Prices and Inflation in Tanzania. Working Papers, African Development Bank Group, No.163, 5-29. https://doi.org/10.2307/2534073

Badan Pusat Statistik. (2017). Kajian Konsumsi Bahan Pokok 2017. Diakses melalui: http://bps.go.id

Baltagi, B. H. (2005). Econometric Analysis of Panel Data. In John Wiley \& Sons Ltd (3th ed., Vol. 5, Issue 7). John Wiley \& Sons Ltd. https://doi.org/10.3109/00498257509056115

Baltagi, B. H. (2015). The Oxford Handbook of Panel Data. Oxford University Press.

Bank Indonesia. (2016). Statistik Ekonomi Keuangan Indonesia. Jakarta, Indonesia.

Bank Indonesia. (2020). Statistik Ekonomi Keuangan Indonesia. Jakarta, Indonesia.

FOA, F. and A. O. of the U. N. (2013). Food Outlook. 69-74.

Gujarati, D. N., \& Porter, D. . (2009). Single-equation regression models. In Introductory Econometrics: A Practical Approach (5th ed.). Douglas Reiner.

Ismaya, B. I., \& Anugrah, D. F. (2018). Determinant of Food Inflation : the Case of Indonesia. Bulletin of Monetary Economics and Banking, 21(1), 81-94.

Kemendagri, K. P. R. I. (2019). Analisis Perkembangan Harga Bahan Pangan Pokok diPasar Domestik dan Internasional. In Pusat Pengkajian Perdagangan Dlama Negeri, Badan Pengkajian dan Pengembangan Perdagangan, Kementerian Perdagangan Republik Indonesia. https://doi.org/10.22219/sm.v5i1.4216

Kornher, L., \& Kalkuhl, M. (2013). Food price volatility in developing countries and its determinants. Quarterly Journal of International Agriculture, 52(4), 277-308. https://doi.org/10.22004/ag.econ.173649

Krugman, P., \& Wells, R. (2018). Macroeconomics (Fifth Edit). Worth Publishers. 
Mankiw, N. G. (2019). Macroeconomis, 10th Edition. In Worth Publishers.

Nopirin (2014). Pengantar Ilmu Ekonomi Mikro-Makro. Yogyakarta: BPFE-Yogyakarta

Pratikto, R., \& Ikhsan, M. (2016). Inflasi Makanan dan Implikasinya terhadap Kebijakan Moneter di Indonesia. Jurnal Ekonomi Dan Pembangunan Indonesia, 17(1), 58-74. https://doi.org/10.21002/jepi.v17i1.658

Rangasamy, L. (2011). Food Inflation in South Africa : Some. South African Journal of Economic, 79(June), 184-201.

Rizaldy, D. Z. (2017). Pengaruh Harga Komoditas Pangan Terhadap Inflasi Di Kota Malang Tahun 2011-2016. Jurnal Ekonomi Pembangunan, 15(2), 171. https://doi.org/10.22219/jep.v15i2.5363

Roache, S. K. (2010). What Explains the Rise in Food Price Volatility? IMF Working Papers, 10(129), 1. https://doi.org/10.5089/9781455201129.001

Rostow, W. W. (1959). The Stages of Economic Growth. The Economic History Review, 12(1), $1-16$.

Saraswati, B. D., \& Kaluge, D. (2017). Perilaku Inflasi 33 Propinsi di Indonesia. MediaTrend, 12(1), 35-44. https://doi.org/10.21107/mediatrend.v11i2 